\title{
Hubungan Riwayat Kanker, Keputihan dan Aktifitas Terhadap Pemeriksaan Inspeksi Visual Asetat (IVA)
}

\author{
Sandi Ari Susiatmi ${ }^{1}$, Nur Chabibah ${ }^{2}$, Risqi Dewi Aisyah ${ }^{3}$ \\ 1. Universitas Muhamamdiyah Pekajangan Pekalongan, email: sandi.kedungwuni@gmail.com \\ 2. Universitas Muhamamdiyah Pekajangan Pekalongan \\ 3. Universitas Muhamamdiyah Pekajangan Pekalongan
}

\begin{abstract}
Abstrak. Organisasi kesehatan dunia (WHO) mengungkapkan data adanya penambahan jumlah penderita kanker sebanyak $20 \%$ pertahun. Hal ini dianggap sebagai masalah yang sangat serius. Di Indonesia kanker serviks menempati posisinomor dua setelah kanker payudara. Kanker serviks banyak menyerang kaum wanita di Indonesia maupun di dunia. Di seluruh dunia, sebanyak 1,4 juta wanita menderita kanker serviks. Penelitian ini bertujuan mengetahui hubungan riwayat kanker, keputihan dan aktivitas harian terhadap pemeriksaan Inspeksi Visual Asetat(IVA). Dalam penelitian ini digunakan metode penelitian analitik observasional dengan pendekatan potong lintang (cross-sectional) dengan teknik proporsional random sampling terhadap 206 responden. Analisa data yang digunakan dalam penelitian ini menggunakan uji Fisher. Hasil penelitian 20,333\% responden mengalami keputihan, 99,03\% responden melakukan aktivitas harian dengan baik, dan 4,85\% dengan hasil pemeriksaan IVA positif. Pemeriksaan IVA di pengaruhi oleh Riwayat Kanker sebelumnya (p-value $=0.000)$ dan aktifitas harian yang dilakukan oleh responden $(p$ value $=0.003)$. Simpulan dari penelitian ini tidak ada hubungan yang signifikan pada hasil pemeriksaan IVA dengan kejadian keputihan. Terdapat hubungan yang signifikan antara hasil pemeriksaan IVA terhadap riwayat kanker dan aktifitas harian.
\end{abstract}

Kata kunci : riwayat kanker, keputihan, aktivitas, hasil inspeksi visual asetat

\section{Relationship History of Cancer, Leurcorrhoea and Activities on The Result of Visual Inspection of Acetate}

Abstract. WHO states that cancer is a very serious health problem because the number of sufferers increases by around $20 \%$ per year. Breast cancer is the second type of cancer in Indonesia that attacks women after cervical cancer (cervix). In other words, cancer cervix is the number one most attacking women in Indonesia. Around the world, cases of cervical cancer have been experienced by 1.4 million women. The purpose of this study was to determine the relationship of cancer history, vaginal discharge and daily activity to the results of visual acetate inspection. This research method is an observational analytic study with a cross-sectional approach with proportional random sampling technique for 206 respondents. Analysis of the data in this study using Fisher's exact test. The results of the study most of the respondents who participated in the IVA examination were aged less than 20 years, with multipara parity and not working or as a housewife. IVA examination is influenced by previous Cancer History (pvalue $=0.000)$ and daily activities carried out by respondents ( $p$ value $=0.003$ ). The results of the study $20.333 \%$ of respondents experienced vaginal discharge, $99.03 \%$ of respondents did good daily activities, and $4.85 \%$ with a positive IVA examination. IVA examination is influenced by previous Cancer History $(p$-value $=0.000)$ and daily activities carried out by respondents $(p$ value $=0.003)$. The conclusion from this study there is no significant relationship between the results of IVA examination with the incidence of vaginal discharge. There is a significant relationship between the results of IVA examination on the history of cancer and daily activities

Keywords : cancer history, leukorhea, daily activity, inspeksi visual acetat result

\section{Pendahuluan}

Menurut WHO, masalah kesehatan yang harus ditangani secara serius salah satunya adalah kanker serviks, dimana terdapat penambahan jumlah kasus sebanyak $20 \%$ setiap tahunnya. Kanker leher Rahim menempati urutan kedua sebagai kanker yang banyak menyerang kaum wanita di Indonesia. Urutan nomor satu adalah kanker payudara. Kejadian kanker serviks ini sudah dialami oleh 1,4 juta wanita di seluruh dunia. Data jumlah penderita kanker dari WHO diketahui terdapat 493.243 kasus baru penderita kanker serviks, dengan 
angka kematian sejumlah 273.505 kasus per tahun (Fuadah, et.al, 2019).

Kanker adalah salah satu penyebab kematian terbesar di seluruh dunia. $30 \%$ kasus kematian karena kanker terjadi karena beberapa factor risiko, diantaranya adalah indeks massa tubuh yang tinggi, minimnya konsumsi buah dan sayuran, kurang aktivitas fisik/olah raga, merokok dan mengkonsumsi alcohol yang berlebihan.

Diantara lima factor risiko tersebut, aktivitas merokok adalah faktor risiko utama kanker yang menyebabkan terjadinya lebih dari $20 \%$ kematian akibat kanker di dunia dan sekitar $70 \%$ kematian akibat kanker paru di seluruh dunia. Selain itu, kanker yang menyebabkan infeksi virus seperti virus hepatitis $\mathrm{B} /$ hepatitis $\mathrm{C}$ dan virus human papilloma berkontribusi terhadap $20 \%$ kematian akibat kanker di negara berpenghasilan rendah dan menengah (Limpens, M.,2018 dalam Sartrika, 2020).

Faktor yang berisiko menimbulkan kanker serviks (kanker leher rahim) pada usia menikah, semakin dini / usia muda melakukan hubungan seksual semakin berisiko terkena kanker serviks. Seorang perempuan yang sudah aktif melakukan hubungan seksual juga merupakan faktor risiko terkena kanker serviks. Sering berganti ganti pasangan seksual dapat meningkatkan risiko untuk terjadinya kanker serviks. Selain itu, factor paritas, yaitu pada ibu yang sudah melahirkan anak, semakin banyak anak yang dilahirkan semakin tinggi risiko terjadi kanker serviks. Kebiasaan merokok juga diketahui meningkatkan risiko kanker serviks akibat dari paparan asap rokok yang masuk ke system pernapasan. Pernah menderita penyakit menular seksual dapat memudahkan penularan HPV (Rasjidi, 2017; dalam Mawaddah, 2020).

Berbagai upaya telah dilakukan baik bersifat promotif, preventif maupun kuratif. Cancer serviks seringkali ditemukan pada saat stadium lanjut sehingga sulit diobati. Upaya deteksi dini cancer serviks menjadi sangat penting sehingga cancer serviks dapat dideteksi sedini mungkin dan mendapat pengobatan (Pranoto, et al. 2020). Lesi pra kanker serviks yang sangat dini dikenal dengan Neoplasia Intraepitelial Serviks (NIS) atau Cervical Intraepithelial Neoplasia (CIN) ditandai dengan adanya perubahan displastik epitel serviks.Terminologi dari lesi preinvasif serviks telah mengalami perubahan. Salah satu alat skrining adanya kanker serviks adalah menggunakan metode pemeriksaan inspeksi visual asetat(IVA). Pemeriksaan IVA merupakan test yang sederhana, efektif, tidak mahal dan dapat dikerjakan oleh tenaga kesehatan misalnya bidan, tidak harus dengan dokter obsgyn. Hasil pemeriksaan IVA dengan hasil positif diduga sebagai lesi prakanker servik (Mawwadah, 2020)

Oleh karena itu peneliti tertarik mengambil judul "Hubungan Riwayat Kanker, Keputihan dan Aktifitas Harian terhadap Hasil Pemeriksaan IVA".

\section{Metode}

Penelitian ini menggunakan jenis penelitian analitik observasional dengan pendekatan potong lintang (cross-sectional), yaitu menganalisis faktor keputihan, obesitas, riwayat kanker, aktivitas berhubungan dengan hasil Pemeriksaan Inspeksi Visual Asam Asetat di Kabupaten Pekalongan. Dalam penelitian ini, populasi yang digunakan adalah seluruh wanita usia subur (WUS) di Wilayah Kabupaten Pekalongan. Pengambilan sampel penelitian adalah dengan menggunakan proportional random sampling. Ukuran sampel yang diperkirakan menurut desain analisis data yang dilakukan yaitu analisis multivariat yang melibatkan 4 variabel independen dan satu variabel dependen. Dalam model analisis multivariat dibutuhkan 15-20 subjek penelitian per variabel jadi total populasi dalam penelitian ini wanita usia subur (WUS) yang memeriksakan IVA sejumlah 206 orang.

Penelitian ini bertujuan untuk mengetahui hubungan antara keputihan, riwayat kanker, aktivitas harian terhadap pemeriksaan IVA, dimana definisi keputihan yang digunakan adalah sekresi yang yang keluar dari jalan lahir wanita yang terjadi dalam rentang periode waktu yang cukup lama baik fisiologis maupun patologis, Riwayat kanker sebelumnya didefinisikan riwayat kanker yang pernah di derita oleh klien, sedangkan aktivitas harian dalam penelitian ini di definisikan jawaban yang diberikan responden mengenai aktivitas/ olahraga yang dilakukan.

Alat pengumpulan data yang digunakan peneliti didalam melakukan penelitian ini adalah kuesioner pertanyaan tertutup (closed ended question). Pada penelitian ini peneliti mendatangi setiap responden yang dijadikan 
sampel dalam penelitian dan menjelaskan maksud penelitian serta langkah pengisian kuesioner, apabila menyatakan mau untuk menjadi responden selanjutnya terlebih dahulu mengisi lembar persetujuan responden. Setelah reponden mengisi lembar persetujuan responden, maka responden mengisi lembar kuesioner. Jika pertanyaan dalam kuesioner sudah dijawab maka kuesioner di bawa dan dikumpulkan oleh peneliti.

Analisa data yang digunakan didalam penelitian ini yaitu menggunakan uji Fisher, untuk melihat adanya hubungan dengan dengan melihat nilai kemaknaanya, yaitu untuk melihat hubungan keputihan dengan hasil pemeriksaan IVA, hubungan obesitas dengan hasil pemeriksaan IVA, hubungan riwayat kanker dengan dengan hasil pemeriksaan IVA, dan hubungan aktivitas dengan hasil pemeriksaan IVA. Tingkat kemaknaan pada uji ini adalah $p$-value $<0,05$ pada rentang intervensi kepercayaan $95 \%$.

\section{Hasil Penelitian}

Distribusi frekuensi responden dalam penelitian ini meliputi :

Tabel 1 Distribusi frekuensi responden

\begin{tabular}{lcc}
\hline \multicolumn{1}{c}{ Variabel } & \multicolumn{2}{c}{ Jumlah (\%) } \\
\cline { 2 - 3 } Umur & \multicolumn{2}{c}{$\mathbf{n}=70$} \\
Kurang Dari 20 & 177 & $85.92 \%$ \\
Tahun & & \\
20-35 Tahun & 28 & $13.59 \%$ \\
Lebih 35 Tahun & 1 & $0.49 \%$ \\
Paritas & & \\
Primi para & 1 & $0.49 \%$ \\
Multipara & 204 & 99.03 \\
& & $\%$ \\
Grande Multi para & 1 & $0.49 \%$ \\
Pendidikan & & \\
Terakhir Ibu & & \\
Tamat SD & 5 & $2.44 \%$ \\
Tamat SMP & 14 & $6.83 \%$ \\
Tamat SMA & 185 & $90.66 \%$ \\
Tamat PT & 1 & $0.49 \%$ \\
Pekerjaan & & \\
IRT & & $95.63 \%$ \\
Buruh & 197 & $2.44 \%$ \\
Pedagang & 5 & $1.44 \%$ \\
Petani & 3 & $0.49 \%$ \\
& 1 &
\end{tabular}

\section{Keputihan}

Ya

Tidak

42

$20.39 \%$

Riwayat Kanker

Ya

164

$76.61 \%$

$10 \quad 4.85 \%$

Tidak

196

$95.15 \%$

Aktivitas

$\begin{array}{lcc}\text { Ada } & 204 & 99.03 \% \\ \text { Tidak } & 2 & 0.97 \%\end{array}$

\section{Hasil Pemeriksaan}

IVA

\begin{tabular}{lcc} 
Negatif & 10 & $4.85 \%$ \\
Positif & 196 & $95.15 \%$ \\
\hline
\end{tabular}

Pada Tabel 1 diperoleh data bahwa sebagian besar dari responden yang mengikuti kegiatan pemeriksaan IVA memiliki usia kurang dari 20 tahun, dengan paritas multipara dan sebagai (IRT) ibu rumah tangga.

Tabel 2. Analisis Pengaruh Keputihan, Riwayat Kanker dan Aktivitas Harian terhadap Hasil Pemeriksaan IVA

\begin{tabular}{|c|c|c|}
\hline Variabel & $\begin{array}{c}\mathbf{P} \\
\text { Value }\end{array}$ & $\begin{array}{l}\text { Pearson } \\
\text { Chi2 }\end{array}$ \\
\hline Keputihan & 0.115 & 2.491 \\
\hline $\begin{array}{l}\text { Riwayat } \\
\text { Kanker }\end{array}$ & 0.000 & 14.388 \\
\hline $\begin{array}{l}\text { Aktifitas } \\
\text { Harian }\end{array}$ & 0.003 & 8.912 \\
\hline
\end{tabular}

Berdasarkan tabel 2. di dapatkan bahwa hasil pemeriksaan IVA di pengaruhi oleh Riwayat Kanker sebelumnya (p-value $=0.000)$ dan aktifitas harian yang dilakukan oleh responden $(p$ value $=0.003)$

\section{Pembahasan}

Berdasarkan hasil penelitian diatas, maka peneliti berasumsi bahwa penerapan skrining kanker serviks pada wanita usia subur karena kesadaran responden akan bahayanya kanker yang saat ini dapat diderita oleh setiap umur dan setiap kondisi yang dibuktikan dengan hasil penelitian usia responden yang melakukan skrining kanker serviks umur <20tahun dan >35 tahun, yang juga didukung oleh penelitian 
terkait bahwa skrining kanker serviks lebih didominasi oleh responden dengan usia $>35$ tahun, status tidak bekerja tidak menjadi factor ibu untuk tidak memperhatikan kesehatan reproduksinya, masih banyak sumber informasi tentang bahaya kanker yang dapat ibu ketahui, salah satunya dari kegiatan promotif (Sartika, 2020).

WUS dengan hasil IVA negative tetap harus waspada dan melakukan pencegahan cancer serviks. Skrining yang dilaksanakan secara ideal dan diharapkan memperoleh hasil yang optimal dilakukan tiap 3 tahun sekali pada wanita dengan rentang usia 2560 tahun dan saat usia mencapai 70 tahun dapat dihentikan dengan catatan wanita tersebut tidak memiliki abnormalitas pada hasil pemeriksaan test pap-nya. ( Rasjidi, 2010; dalam Pranoto, 2020)

Responden yang mengikuti kegiatan pemeriksaan IVA sebagian besar adalah multipara (99.03\%). Menurut Wahyuningsih (2016) mengungkapkan bahwa sebagian besar responden dengan paritas $>3$ kali lebih beresiko untuk mengalami lesi prakanker serviks dibanding dengan responden dengan paritas $<3$ kali. Paritas adalah kemampuan wanita untuk melahirkan secara normal. Pada saat menjalani proses persalinan pervaginal, janin akan bergerak melalui jalan lahir dan ada 2 kemungkinan terjadi kerusakan jaringan epitel ini berkembang kearah pertumbuhan sel yang tidak normal yang berisiko berkembang menjadi keganasan. Jika persalinan melalui jalan normal selain terjadinya robekan selaput serviks, dapat mengakibatkan munculnya perubahan sel abnormal. Sehingga mempunyai kesempatan untuk terkontaminasi oleh virus yang menyebabkan infeksi. Bakteri tersebut ada karena kondisi hygiene vagina yang tidak terawat sehingga dapat berkembang menjadi keganasan. Paritas yang berbahaya adalah dengan jumlah anak lebih dari 4 orang atau dengan jarak persalinan yang saling berdekatan. Hal ini dapat menimbulkan munculnya perubahan sel - sel abnormal pada mulut rahim.(Mawaddah, 2020)

Pada tabel 1 memperlihatkan bahwa sebagian besar ibu yang mengikuti pemeriksaan IVA adalah Ibu rumah tangga (IRT) (95.63\%). Ibu rumah tangga lebih banyak waktu dalam mengikuti kegiatan di luar rumah sehingga memungkinkan akses ke pelayanan kesehatan juga lebih memungkinkan. Pendidikan terakhir paling banyak adalah pada tingat pendidikan SMA (90,66\%). Menurut Undang-Undang RI no 20 tahun 2003, jenjang pendidikan adalah tahapan pendidikan yang ditetapkan berdasarkan tingkat perkembangan peserta didik, tujuan yang akan dicapai dan kemampuan yang dikembangkan. Dalam penelitian ini, variable tingkat pendidikan responden terdapat yang berpendidikan rendah lebih banyak yang bersedia memeriksakan diri untuk pemeriksaan IVA karena mayoritas responden adalah ibu rumah tangga (IRT) sehingga memiliki waktu lebih banyak dan lebih fleksibel mengatur waktu untuk pergi ke fasilitas kesehatan melakukan pemeriksaan IVA (Ananti, 2020)

Tabel 2. Menunjukkan bahwa kejadian keputihan yang dialami wanita tidak berhubungan pada hasil pemeriksaan IVA secara statistic ( $\mathrm{p}$-value $=0.115)$. Kejadian keputihan patologis merupakan tanda dari adanya infeksi pada genetalia. Akan tetapi kejadian keputihan yang bersifat fisiologis dapat di kaitkan dengan personal hygiene yang tidak baik. Pada Penelitian Baturbatur menyimpulkan bahwa ibu pemulung memiliki personal hygiene yang baik tidak mengalami keputihan, disisi lain banyak teori mengatakan bahwa keputihan terjadi bukan hanya dari personal hygiene yang buruk saja tapi dapat dipengaruhi dari status gizi, berat badan, pola makan yang tidak teratur, stress dan masih banyak lagi. Pada saat peneliti melakukan wawancara dan membagikan kuisioner, peneliti mengamati kebersihan kulit dari ibu pemulung, terlihat bahwa kebersihan kulit 
ibu memang terlihat kurang bersih, namun setiap ibu pemulung kembali kerumah mereka wajib membersihkan diri mereka Kebersihan tangan, dan kuku yang dimaksud pada penelitian ini adalah kebersihan yang dilakukan pemulung dengan cara mencuci tangan dengan air yang mengalir dan sabun memotong kuku tangan secara teratur (Butarbutar, 2019).

Hasil Pemeriksaan IVA pada Tabel 2 menunjukkan nilai $p$-Value yang berhubungan dengan riwayat kanker sebelumnya $(p$-value $=0.000)$. Kanker adalah penyakit yang berbahaya yang dapat menyebabkan kematian. Salah satu penyebab dari seseorang berisiko menderita penyakit kanker adalah faktor genetik atau keturunan. Jika seseorang mempunyai keturunan penyakit kanker dalam keluarga, kemungkinan berisiko untuk terkena penyakit kanker lebih besar. Dari hasil penelitian variabel riwayat kanker dalam keluarga didapatkan hasil responden dengan riwayat penyakit kanker dalam keluarga berpeluang lebih besar mendapatkan/terkena kanker karena ada bakat/faktor genetik yang sudah ada didalam keluarga (Ananti, 2020).

Sedangkan pola aktifitas keseharian yang dapat mejadikan olahraga yang dilakukan klien minimal sehari selama 30 menit dinyatakan terdapat korelasi yang signifikan secara statistic dengan hasil pemeriksaan IVA (p-value $=0.003)$. Hal ini memungkinkan hubungan secara tidak langsung antara aktifitas harian dengan hasil pemeriksaan IVA. Dimana menurut penelitian sebelumnya bahwa kegiatan olah fisik yang baik dan teratur seperti senam, jalan-jalan pagi, berlari-lari dengan cepat, mengangkat barang belanjaan, dan melakukan pekerjaan rumah tangga dapat membantu meningkatkan pola hidup yang sehat dan meningkatkan kenyamanan dalam kualitas tidur (Laili, 2018).

\section{Simpulan}

Tidak ada hubungan yang signifikan dari hasil pemeriksaan IVA dengan kejadian keputihan. Ada hubungan yang signifikan antara hasil pemeriksaan IVA terhadap riwayat kanker dan aktifitas keseharian.

Saran Perluasan aspek dalam instrument penilaian sehingga data yang di peroleh dalam penelitian lebih dapat membahas secara mendalam kejadian keputihan yang dirasakan oleh responden.

\section{Daftar Pustaka}

Ananti, Y., \& Sari, F. (2020). Hubungan Sosiodemografi Wanita Usia Subur Dengan Perilaku Deteksi Dini Kanker Serviks Metode IVA. Jurnal Kesehatan Samodra Ilmu, 11(1), 76-83.

Butarbutar, A. F., \& Tumanggor, J. F. (2020). Hubungan Personal Hygiene Dengan Masalah Keputihan Pada Ibu Pemulung Di Tpa Tadukan Raga Stm Hilir. Jurnal Kesmas Dan Gizi (JKG), 2(2), 119-125.

Fuadah, F., Rejeki, S., Triana, H., \& Purnasari, H. (2020, February). Deteksi Dini Kanker Serviks Melalui Pemeriksaan IVA Test Pada Wanita Usia Subur Di Desa Babakan Kecamatan Ciparay Kab Bandung. In Prosiding Seminar Hasil Penelitian dan Pengabdian kepada Masyarakat Unjani Expo (Unex) (Vol. 1, No. 1, pp. 47-49).

Laili, F. N., \& Hatmanti, N. M. (2018). Aktivitas Fisik Dengan Kualitas Tidur Lansia Di Posyandu Lansia Wulan Erma Menanggal Surabaya: Physical Activity With Sleep Quality In Elderly Posyandu Wulan

Mawaddah, S., \& Susanti, I. D. (2020). Hubungan Paritas, Usia Perkawinan Dengan Resiko Lesi Prakanker Serviks Pada Pasangan Usia Subur Di Kelurahan Petuk Bukit. MMJ (Mahakam Midwifery Journal), 5(1), 1-11. 
Jurnal Ilmiah Kesehatan Vol XIII, No II, September 2020 ISSN 1978-3167, E-ISSN 2580-135X

Pranoto, H. H. (2020). Resiko Aktifitas Seksual Pada Usia Muda Terhadap Hasil Deteksi Dini Kanker Cerviks Di Kabupaten Temanggung. Jurnal Ilmu dan Teknologi Kesehatan, $11(1)$.

Sartika, T. (2020). Analisis Pelaksanaan Skrining Kanker Serviks Pada Wanita Usia Subur. Jurnal'Aisyiyah Medika, 5(1). 